\title{
A Comparative Study of the Story of Esfandiar in Ferdowsi's Shahnameh and Achilles in Homer's lliad
}

\author{
Dr., Masoumeh Sadeghi \\ Faculty member of Islamic Azad University, Garmsar branch \\ Masoumeh_Sadeghi@ymail.com
}

\section{Doi:10.5901/jesr.2013.v3n7p550}

\section{Abstract}

\begin{abstract}
Epic is a kind of descriptive poem which is based on describing heroic and manhood actions and prides of a nation or person so that it includes different symbols of their life.lliad and Odysses of Homerus, Ramayana and Mehabeharatay of Indians and Shahnameh of Ferdowsi are three great epics of the world. These three epic works are related to Aryan race which has been divided into different branches and everyone has been settled in a land and this is why that there are some common characteristics between them. As epic of every nation is a mirror that shows their culture, nature and endogenous life, these relations and coordination of two Iranian and Greek epics, Shahnameh and lliad and Odysses show proximity of the two nations in mirror of history. Shahnameh has been divided into three mythological, heroic and historical parts lliad and Odysses has been also composed by Homerus, famous Greek poet. Iliad book includes explanation of ten years war between Greece and Troas in 24 chapters and Odysses, which has 24 poems, is about Olis, one of heroes of Troas war and figures his braveries. These two great epics which show two known old culture, can be compared from different characteristics. There are many behavioral likenesses in view of individual, social relationships and acquaintance with different kinds of their natures in addition to structural likenesses. Existence of heroes such as Esfandiyar and Achilles, greedy and chimerical kings such as Keykavoos and Agamemnon, experienced masters such as Piran and Odysses, beautiful and sly women such as Soodabeh and Helen and devotedand portentous teenagers such as Bahram and Patrocelos, all show much likeness of these two epics. As one of important elements of epic texts is heroic element and Esfandiyar and Achilles are two considered heroes in shahnameh and lliad and their life is similar to each other and both are invulnerable heroes of Iran and Greece who their bravery determined fate of two nations, we decided to introduce story of Esfandiyar and Achilles after defining epic and its elements and introducing Shahnameh of Ferdowsi and lliad of Homerus and explaining likeness of them and explain likeness and difference between these two story while figuring bravery of this two invulnerable heroes of Iran and Greece.
\end{abstract}

Keywords: epic, Shahnameh, lliad, Esfandiyar, Achilles,invulnerable.

\section{Introduction}

The word Epic means "courage, bravery, praise and it is a kind of poem in which one talks about war and bravery" (Safipoor; 275), and as a term it means "a long poem about behavior and deeds of heroes and championship and honorable events in the ancient life of people" (Mokhtari, 1368:21). The characteristics of this genre are greatness and glory of the warriors and prominence of the theme and the heroes of the Epic events that need to be complete in every aspect in a way that their errors are part of the heroic side of the story (Seyyed Hosseini, 1351: 52-53).

There are two different kinds of Epic: natural and artificial. The origin of the natural Epic is a historical or quasihistorical event. From a basic and mythological point of view, this kind of epic does not have a specific compiler but people from all generations compile this kind of Epic (Razmjoo, 1374: 51). In other words natural epic is "the result of thoughts, Talents and emotions of a nation to express the greatness and genius of the people throughout the time, and it is full of descriptions on battles, sacrifices of the heroes, and dedications of that nation" (Safa, 1352: 5-6). Some examples for this type of epic are Homer's lliad and Odyssey, Ramaya and Mahabharata from India, and Ferdowsi's Shahnameh.

Artificial epic is a duplication of the natural epic, because its elements are borrowed from epic. In the artificial epic not all the people are involved in forming the stories; but only one poet forms and creates it. In fact this kind of epic is a reinvention rather than a creation (Razmjo0, 1374: 5-6). Some examples for artificial epic are Aeneid by Virgil and Khavaran Nameh by Ibn Hessam.

Epic can also be classified in to Mythological heroic, historical and religious based on the theme and content.

Mythological epics are stories with unknown historical origins. For nomadic tribes, mythology was the basis of 
beliefs and faith; but by the development of nation's knowledge and information, mythology lost its value as a source of belief and remained a story. (Daad, $1378: 26)$. Mythology was often considered as a source of inspiration for poets and authors. In epical texts of every nation a great part of the stories which express a nation's culture and civilization are expressed through myths.Two world's famous epics are Ferdowsi's Shahnameh and Homer's lliad with an ethnic and national mythology include national heroes' bravery and courage. Shahnameh was composed by Hakim Abol-Ghasem Ferdowsi. Ferdowsi was from the farmers' class in Toos. He was interested in the Iranian culture and decided to write Shahnameh at the age of thirty five. He used different references like Mansour Abu-mansouri's Shahnameh and Khodainameh and tried to express his own thoughts in various fields such as advice, praise of wisdom, truth and goodness.

Shahnameh is about the history of Iran from the creation of the first human being and the first king until the Imperial extinction in Iran by the Arabs. The content of this book is organized into three mythological, heroic and historical parts.

Iliad was written by Homer, the famous poet and story teller of Greece, who lived around 800 B.C. There is not enough information about Homer's life and there are mostly myths and fictions which were compiled and written later. According to these legends, he became blind at the end of his life and travelled to different cities to play harp and sing his lyrical poems for people. What made Homer an everlasting feature in Greek literature is that he described about the history and mythology of the Ancient Greece for the first time in his two epical works of lliad and Odyssey. lliad is Greece's most ancient epic. This book contains twenty four poems the topic of which is the battle between Greece and "Troy". This historical event is mixed with myths and legends. Gods and legendary heroes of Greece are talked about in this epopee.Both Shahnameh and lliad have the fundamental mysteries of epic as an art. Both epopees express the successful and permanent attempts of the artists who tried to perpetuate a nation's glory and identity (Rastegar Fasaei, 1384: 12).

Comparison of Shahnameh and lliad reveals that Ferdowsi was influenced by Homer's lliad in some of the stories of Shahnameh. Professor Mehrdad Bahar believes that this influence is the result of the Iranian, Indian neighbor and the attacker Greece's cultural integration at the time of Kushanian reign in the East of Iran (Bahar, 1384: 240). This integration makes some epical stories in India, Iran and Greece similar to each other. In fact these similarities are by no means accidental, but due to some historical events. Immigration of the Greek to the Eastern part of Asia and establishing a Greek government made people from East of Iran familiar with Greek mythology and influenced by Greek stories, and throughout the years there were common grounds between Iranian and Greek mythology which resulted in similarities between Epical stories of Iran and Greece (The seam source: 58-65).

One of the stories in Shahnameh which is influenced by Homer's lliad is the story of "Rostam and Esfandiyar". This story can be considered as an example of the Iranian and Greek cultural integration. Although this story is part of Shahnameh and the story of Hector and Achilles is formed at the end of lliad during the war between Greece and Troy, they have many commonalities from the beginning up to the end. These common points can be seen in the characters, geographical location of the events and the endings of the two stories. In the present article, after narrating a summary of both stories, a comparative analysis of the similarities and difference between these two stories will be made.

\section{The story of Rostam and Esfandiar}

Esfandiar is an Iranian hero and an invulnerable prince. He is the son of Goshtasb, the Kiani king. Goshtasb who was crowned when his father Lohrasb was still alive, repeatedly promises handling over the kingdom to his son, but does not keep his promise. The first time was when Goshtasb wants to send him to fight Arjasp, king of the Turanians, because of revenge for zarir. Goshtasb promises to leave him the crown if he wins the battle. After that Goshtasb promises him the throne if Esfandiar spreads Zoroastrianism in the world and brings infidels into this religion. Esfandiar spreads Zoroastrianism all over the world, but again Goshtasb failes to carry out his promise. He not only does not bestow the crown upon him but also orders to jail him in Gunbadan fortress because a person called "Gorazm" speaks ill about Esfandiar. Arjasp attacks Iran. Goshtasp is unable to confront him, therefore, he asks Esfandiar, who is imprisoned, to stand against Turanians, and he accepts. After defeating them, Esfandiar goes to Royin fortress according to the Kayanian king's wish. He rescues his sisters who had been imprisoned there. He takes a lot of risks to save them and passes the Seven Trials, but once again the king reneges on his promise and resorts to another trick so he consults with his minister, Jamasp, to know about Esfandiar's fate. Jamasp, who is an astronomer and predictor, predicts death of Esfandiar by Rostam in Zabolestan. Knowing about this event, Goshtasp asks Esfandiar to go to Zabol and bring Rostam bound. Esfandiar rejects at first but accepts after discussing it with his father and prepares himself to go to Zabolestan. 
His mother, Katayun repeatedly tries to dissuade him from his decision but the Kayanian prince does not pay any attention to his mother's words. Rostam warned him repeatedly not to fight in Zabolestan, but he refrains and finally war breaks out between them. Rostam becomes wounded and helpless. Zal, Rostam's father, asks Simurgh to help him and Simurgh shows Rostam how to kill Esfandiar, and teaches him how to make an arrow to hit the eyes of Esfandiar, his weak spot, so Esfandiar is killed by Rostam.

\section{The story of Achilles and Hector}

The story of Achilles happens on the tenth year of the war between Greece and Troy. The main cause of this war was that Helen, Agamemnon's brother's wife, was kidnapped by Paris, the Troy's prince. The story begins with the conflict between Achilles, the Greek general, and Agamemnon, the king of Argos. Agamemnon kidnaps a girl called "Briseis" who was imprisoned by Achilles. Being resentful, Achilles refrains to fight and returns back to his tent.

The goddess Tethys, Achilles' mother, asks Zeus, the king of Greek gods to punish the king's troops for this action. Therefore, Agamemnon and his troops are defeated by Troy's people and Hector, their commander. Regretting his behavior, the Greece king sends his representatives to Achilles and asks Achilles to help him during the battle. First, Aulis, the Greek commander talks to Achilles but the champion still refrains to fight. Then, Patroclus who is Achilles' friend goes to him and asks him for help. Achilles does not accept and provides him with weapons. Patroclus accepts the weapon and goes to fight Hector, but is killed.

Being mad about his friend's death, Achilles wears the armor gods had made him and attacks Troy's troops and kills many of them. One of the dead is Hector, the Troy's corps commander. Achilles fastens the Hector's body to the chariot and turns around Troy's fortifications. Paris, the Troy's prince, shoots the invulnerable Achilles in the heel with an arrow and he is killed. After a hard battle, Greeks return Achilles body back. Achilles' mother, Tethys, buries her son's body magnificently. Finally Greeks defeat Troy's troops and win the battle.

\section{Common points of the two stories}

We have already mentioned about the influence of Homer's lliad on Ferdowsi's story of "Rostam and Esfandiar" and also its similarities with the story of "Achilles and Hector".One of the common points in these two stories is the geographical location of the events. The story of "Rostam and Esfandiar" happens in Zabol and the story of "Achilles and Hector" takes place in Greece. Greece to Troy is just like Iran to Sistan, a big country to a small region.

The other similarity is the characters and champions. Characters in these two stories such as Esfandiar and Achilles, Goshtasp and Agamemnon, Hector and Rostam, Katayun and Tethys, Zal and Paris have many features in common. Esfandiar, the son of Goshtsp is not only a prince but also a champion. None of the other characters in Shahnameh have both of these features "(Eslami Nodoushan, 1376: 353)". "His life is short and he spends all his life in conflicts; but his short life is full of victories and glories. He is the hero of the Zoroastrian religion and claims that he was the one who made the entire world follow it "(Eslami Nodoushan, 1351: 122)". Esfandiar constantly defends Iran against enemies. Achilles, similarly, defends the crown of the Greece king against the Troy.

These two heroes are in conflict with the kings. Esfandiar desires to take his father's kingdom and thinks he deserves it as an award for his deeds. Achilles is also resentful about Agamemnon because he kidnapped his beloved girl.Both heroes talk about the battles and their services to the king, and complain about the king's unkindness towards them. Esfandiar talks to Katayun, his mother, about his bravery and courage in the battle field, his fight with Arjasp and releasing his sisters from the prison of Turanians and complains about his father's inattention (Ferdowsi, 1381: 712-713). In the ninth poem of lliad, Achilles also mentions about his championships and complains that Agamemnon has ignored his deeds and kidnapped his wife (Homer, 1385: 302).

The other common feature between these two heroes is their invulnerability. "Based on Mzdysna tradition and legend, Zarathustra washes Esfandiar in holy water so that he becomes invulnerable and immortal. But because of an instinct and erroneous fear he closes his eyes when he dives into water and his eyes are not washed over and they remain vulnerable (Meskoob, 1342: 29).

Achilles is also believed to be dipped in styx or river of immortality which makes all his body except his heels invulnerable and immortal (Pin Saint, 1380: 199). Both heroes are invulnerable except for a single part of their body which remains vulnerable.One of the most prominent features of Epic is the prediction of events. "Prediction is prevalent in the myths of the world. In Shahnameh most historical events are revealed to the king and champions by priests, astronomers and predictors (Sobhani, 1372: 164). 
As an answer to Goshtasp who asks for the Esfandiar's fate, Jamasp looks at "the ancient horoscopes" and predicts that he would die in Zabolestan. Knowing about his decision about going to Zabolestan, Katayun, Esfandiar's mother, advices him and tries to persuade him not to go. "she feels an ominous fate for his son in her heart as a result of her maternal affection, however, Esfandiar does not accept her mother's advice" (Eslami Nodoushan, 1376: 1362).

Moving to Zabolestan, Esfandiar's camel kneels at a crossroad, one to Zabolestan and the other to Gunbadan fortress to prevent the prince. Esfandiar takes it as a bad omen and orders to kill the camel to turn the infelicity back to the animal (Ferdowsi, 1381: 717).

There are similar predictions in liad too. It was predicted that "if Achilles does not help, they cannot take the Troy and he will win near the city walls and die there" (Homer, 1385:20). Achilles' mother constantly mentions about the early death of her son and prevents him from going to the battle (the same source: 61). Before Achilles goes to the battle field, his swift horse, Xanthus starts to speak and predicts his death (the same source: 90). The death of the two heroes is also similar as both of them are killed by supernatural forces. Esfandiar is killed by Zal and Simurgh, and Achilles in killed by gods.At the moment when Esfandiar is dying, he believes that Goshtasp is the reason for his death and warns him that in the other world he will ask for justice about his father in the sight of God. (Hamidian, 1383: 339).

Rostam and Hector are two other similar heroes in these two epics. Rostam is a great Iranian champion from Sistan. During his long life Rostam greatly helped Iran and the kings; However, when he gets old he stands against Esfandiar and starts an unwanted fight with him.Hector is also an experienced champion who has constantly supported the Troy and the people there. The war between Troy and Greece is unwantedly imposed on him and he is forced to fight with Greek champions (Bahar, 1384:242).

These two champions have got the same physical power and strength. Rostam has sword and mace. He is fullbodied and not every horse can carry him. His food is also much more than a normal human being. Hector is also a very powerful man. When nobody can move a heavy stone, he carries it just like a sheepskin. A common scene in these two stories is when Esfandiar sees Rostam healthy after he was wounded in war. He addresses him and says," it is because of Zal's tricks that you are healthy now, but I fight with you and defeat you so Zal will never see you healthy again" (Ferdowsi, 1381: 736).

Hector is also wounded in one of the wars with the Greeks. His enemy says, "you disobedient, you could survive after you were near death, and Zeus again saved you.... if you come across me again in future, having God by my side, I will kill you" (Homer, 1385: 359).

The other two similar characters in these stories are Goshtasp, king of Iran and Agamemnon, king of Greece. Egoism is their common feature which makes the two champions indignant.

"Goshtasp is an example of a person that has nothing devine as the result of his desire for power. He only thinks about keeping his power. Power is not means for him but ends. To reach this end, he sacrifices the most natural and sacred blessings that is affection for his child" (Rahimi, 1369: 141). He causes Esfandiar to die because of his egoism and ambition not to bestow him the crown. Agamemnon, who is forced to give up Chryseis, Apollon temple priest's daughter, takes Briseis, Achilles beloved, from him to make him annoyed.

Both kings are insipient. Because of indiscretion and ignorance to the country, Goshtasp neglects Arjasp's attack, and this makes Turanian's king attack Iran and Goshtasp's father, Lohrasp, is killed (Ferdowsi, 1381: 673-674). Agamemnon also offends Achilles because of his indiscretion so a lot of problems are made for Greece in the battle with Troy.

Hypocrisy is another common feature of these two kings. When Goshtasp understands about Jamasp's prediction on Esfandiar's death, he appears to be upset, but in reality evil thoughts and fate takes him into dysfunctions (Ferdowsi, 1381: 713). After the offensive behavior of Agamemnon, Achilles also talks about dishonesty and hypocrisy of the king. "..... consider the one whose heart and tongue is not the same as the gate of enemy's hell...." (Homer, 1385: 303).

One of the common points in these two epics is the sanctity and high position of the kings in a way that the others are completely obedient. Although Esfadiar is offended by Goshtasp in Shahnameh, he accepts his demand to fight with Rostam. Achilles can also prevent Brassies to be taken by Agamemnon envoys but he does not stop them.Zal and Paris are the other two similar characters in these stories. From the first beginning day of his life, Zal is considered as a sinister and ominous child and he is rejected by his family and his father, Sam. Simurgh brings him up and helps him do great things. Paris is also rejected at a young age because of his infelicity; because it was predicted that his existence leads to the destruction of Troy. He is brought up by a bear, later on he is connected to gods and does supernatural actions.

The other common characters are the mothers of these two heroes. Their behavior, their words and advices to their children are the same. Katayun, Esfandiar's mother, becomes sad when she understands about Goshtasp's demand and when she sees her son's determination to go to Zabolestan. She calls her son as "suffered" with tearful 
eyes and advices him not to desire for the crown at the expense of his life (Ferdowsi, 1381: 716-717). Tethys, Achilles' mother, also advices her son with tearful eyes as she knows about Agamemnon's oppression, "....My son, woe is me that I should have borne or suckled you. Would indeed that you had lived your span free from all sorrow at your ships, for it is all too brief; alas, that you should be at once short of life and long of sorrow, therefore, was the hour in which I bore you.....nurse your anger and hold aloof from fight" (Homer, 1385: 64).

The other common feature in these two stories is the presence of supernatural elements and their involvement in the events. In the story of Esfandiar, when Rostam is injured by the Kayanian prince, he goes to his father, Zal, and Zal asks Simurgh to help him save Rostam's life. Simurgh pulls out the arrows from his wounded body and puts his feathers on his wounds as salve. Immediately after, Rostam, the Iranian world champion, recovers (Fersowsi, 1381: 747-748).

In lliad also gods help the heroes in the battle field. Achilles meets Athene, Greece's goddess, and asks why she is there. She replies: "I came from the heavens to quell your anger". (Homer, 1385: 215).

Elsewhere, when the distressful Achilles goes to the waterside, and starts to cry and calls Tethys, his mother for help, siting beside her father, she hears Achilles' words and rises from sea's depths like white steam and stands in front of her son (the same source: 270 ).

These two stories can also be compared from the tragedy point of view. "Tragedy is the illustration of important and serious deeds that are generally disadvantageous to the protagonist, i.e. the main core of a serious story leads to a tragedy at the end. This tragedy is usually the death of the hero in the story. This death is not accidental, but a logical and direct result of the events throughout the story" (Shamisa, 1367: 93).

In the story of "Rostam and Esfandiar" events develop in ways that result in the death of Esfandiar at the end. Goshtasp asks Esfandiar to bring Rostam to him; Katayun insists to prevent Esfandiar from confronting Rostam; the camel kneels and does not move and the prince does not pay any attention to it; Esfandiar ignores Rostam's words for peace and compromise and straying away from fight; Rostam doubts about fighting Esfandiar which all lead to the death of this great Iranian champion. All these events show that there is a force from the very beginning of the story up to the end. This inevitable force forms the tragedy at the end.

The story of Achilles is also an example of a tragedy. In this story, the events happen in ways that lead to the death of the hero at the end. Kidnapping Achilles' beloved by Agamemnon, the murder of his friend, Patroclus, in the battle of Troy, Achilles ignoring his mother's words when she prevents him from fight, the horse's prediction and going to fight while being reluctant all lead to a tragedy. Both stories end with the death of the heroes and they are full of sorrows and griefs.

\section{The differences between the two stories}

Although there are many similarities between the two stories, there are some differences too. The story of "Rostam and Esfandiar" has more unity of theme than the story of Achilles and Hector in lliad. The focus is not on two or more characters in lliad. Even gods appear during the story and show their power. But the story of "Rostam and Esfandiar" focuses on the conflict between the two champions and their conversations. The outside elements and characters like Katayun, Bahman, Zal, Simurgh etc. are talked about peripherally (Mohammad Kashi, 1386: 105).

The other difference is about the way the two stories start. "In the story of lliad, the main reason for the fight is saving Helen, the wife of Menelaus, Agamemnon's brother, that leads to Greece and Troy battle for ten years. However, in the story of "Rostam and Esfandiar" the reason for the conflict between Rostam and Esfandiar is Goshtasp's refusal to bestow the crown to Esfandiar". (Rastegar Fasaei, 1384: 13). In other words in lliad, kidnapping of a woman creates a tragedy but in the story of "Rostam and Esfandiar" the tragedy occurs through the hegemonism of the Kayanian prince and his conflict with Rostam and the bravery and courage of these heroes lead to a tragedy.In the story of "Rostam and Esfandiar" Katayun just acts as a mother, while Achilles' mother not only has a maternal role but also is the goddess of the seas and she makes major decisions. For example in the battle of Greece and Troy, she asks Zeus to finish the fight in favor of the Troy and her request is fulfilled (Ghasemzadeh, 1388: 43).

Revenge is more harsh in lliad. Achilles goes to fight to avenge the death of his friend, Patroclus. However, in the conflict between Rostam and Esfandiar this revenge is less harsh and it forms a small part of the story. Esfandiar's sons, Mehrnoosh and Azarnoosh, are murdered by Rostam's relatives and this makes Esfandiar more intent to fight Rostam but revenge is not the main reason of this fight.

Although the supernatural elements like Simurgh in the story of Rostam and Esfandiar is involved in the death of Esfandiar and causes the tragedy, it only has an indirect and guiding role in the story. However, in lliad gods have direct roles in the humans' fate. For example, Achilles' mother who is a goddess is present from the beginning of the story to 
the end and she plays a major role in her son's fate.The other difference between the two stories is the death of the two heroes. In lliad Achilles is not murdered by Hector but he is killed by Paris, Troy's prince. Whereas Esfandiar is killed by Rostam.

\section{Conclusion}

The comparative analysis of epics like Ferdowsi's Shahnameh and Homer's lliad and Odyssey reveals some similarities. These similarities show that Ferdowsi has been influenced by Homer when he creates Shahnameh. This influence origins from history and the neighborhood of the Iranians from the East and Greek Immigrants from Eastern Asia.The story of Rostam and Esfandiar is one of the stories which has been affected by the story of Achilles in lliad. The comparison of these two stories shows that there are many similarities between the protagonists, Esfandiar and Achilles. These common points are championship, invulnerability, courage, bravery prediction of their death and supernatural powers that cause their death.

The other characters in these stories like Rostam and Hector, Goshtasp and Agamemnon, Zal and Paris, Katayun and Tethys also have many similarities. Moreover, the specific characteristic of the two stories is the tragedy that leads to the death of the two champions. The points of differences between the two stories are unity of the theme, main reason for the fight, and the status of the women. In the story of Rostam and Esfandiar, more unity is observed in the theme of the story compared to the story of Achilles and Hector. The major reason for the fight in Iliad is kidnapping a woman, while in Shahnameh it is Hegemonism. Revenge in the story of Achilles is also more harsh compared to the tragedy of Esfandiar.

\section{References}

Eslami Nodoushan, M. A. (1351). (the story of stories). Tehran: Anjoman-e Asar-e Melli.

(1376). (life and death of the heroes in Shahnameh). Tehran: Nashr-e asar.

Bahar, M. (1384). (from mythology to history). Tehran: Cheshmeh.

Pin Saint, J. (1380).(Greek myths). Translated by Bajelan Farrokhi. Tehran: Asatir.

Hamidian, S. (1383). (An introduction to Ferdowsi's thoughts and art). Tehran: Nahid.

Daad, S. (1378). (Dictionary of literary terms). Tehran: Morvarid.

Rahimi, M. (1369). (The Tragedy of power in Shahnameh). Tehran: Nilofar.

Razmjoo, H. (1374). (Genres in literature: Effects on Persian language). Mashad: Astan-e Ghods-e Razavi.

Rastegar Fasaei, M. (1384). (The epic of Rostam and Esfandiar) Tehran: Jami.

Sohani, T. (1372). (The history of Iran literature). Volume I. Tehran: Payam-e Nour.

Seyyed Hosseini, R. (1351). (schools of literature). Tehran: Neil.

Shamisa, S. (1367). (Genres in literature). Tehran: payam-e Nour.

Safa, Z. (1352). (Epic in Iran: From the ancient time to the 14th century). Tehran: Amir khabir.

Abdol Rahim Ben Abdolkarim, S. (n.d). (Dictionary of Arabic to Persian). Tehran: Sanaei.

Fersowsi, A. (1381). (Fersowsi's Shahnameh by Saeed Hamidian). Tehran: Ghatre.

Ghasemzadeh, M. (1388). (From Sistan to Troy). Roshd, Foreign languages and literature, 90, 38-43.

Mohammad kasha, S. (1386).(looking for the origins of a story, lliad and Shahnameh). Journal of Ettela Resani va ketabdari " Ketab Mah Honar". 107, 108: 94-107.

Mokhtari, M. (1368). (Epic in National mysteries). Tehran: Ghatreh.

Meskoub, S. (1342). (An introduction to the story of Rostam and Esfandiar). Tehran: Amir Kabir.

Homer. (1385). (lliad). Translated by Saeed Nafisi. Tehran: Jami. 